\title{
Mechanical behaviour of rammed earth column: A comparison between unreinforced, steel and bamboo reinforced columns
}

\author{
D. D. Tripura ${ }^{\mathrm{a}} \bowtie ;$ K. D. Singh ${ }^{\mathrm{b}}$ \\ a. Department of Civil Engineering, National Institute of Technology Agartala, (Tripura, India). \\ b. Department of Civil Engineering, Indian Institute of Technology Guwahati-(Assam, India). \\ $\triangle$ debdulaltripura@gmail.com \\ Received 1 November 2017 \\ Accepted 3 May 2018 \\ On line first 14 September 2018
}

\begin{abstract}
This paper presents an experimental study on the behavior of cement stabilized rammed earth (CSRE) column reinforced with steel under axial loading and its comparison with unreinforced and bamboo reinforced columns. Effects of structural parameters such as tie / stirrup spacing on the failure pattern, lateral and axial deformation of columns are studied. Test results show that the load-capacity of columns increases with increase in lateral / tie reinforcement ratio. Maximum axial and lateral deformations occur in columns with least tie spacing. Behavior of CSRE columns reinforced with close tie spacing is characterized by gradual spalling of cover at the failure zone. Steel reinforced columns perform better than other column types in terms of load-capacity; hence it may be used as structural member adjacent to walls for low-rise rammed earth houses. Proposed reinforcement technique can be adopted in the field for enhancement of greater strength and performance of columns.
\end{abstract}

KEYWORDS: Portland cement; Steel; Compressive strength; Composite; Curing

Citation/Citar como: Tripura, D.D.; Singh, K.D. (2018) Mechanical behaviour of rammed earth column: A comparison between unreinforced, steel and bamboo reinforced columns. Mater. Construcc. 68 [332], e174 https://doi. org/10.3989/mc.2018.11517

RESUMEN: Comparación del comportamiento mecánico de pilares de barro sin armadura con los armados de acero o de bambú. En este trabajo se presentan los resultados experimentales del comportamiento ante cargas axiales de pilares de barro estabilizados con cemento (CSRE, por sus siglas en inglés) y armados de acero, así como la comparación de dicho comportamiento con el de los pilares sin armadura y los armados de bambú. Se estudian los efectos producidos en la modalidad de rotura y en la deformación tanto lateral como axial de los pilares por parámetros estructurales como la distancia entre cercos o estribos. Los resultados de los ensayos indican que la capacidad portante de los pilares aumenta con el incremento de la relación armadura lateral/ cerco. Las deformaciones máximas axial y lateral se observan en los pilares en los que el espaciado de los cercos es menor. En los pilares CSRE armados con cercos poco distanciados, ante las solicitaciones aplicadas se produce el desprendimiento del recubrimiento en la zona de rotura. Los pilares armados de acero presentan mayor capacidad portante que los otros estudiados, pudiendo emplearse por tanto como elemento estructural de los muros de las casas de barro de media altura. La adopción en obra de la técnica de armar propuesta permitiría mejorar la resistencia y el rendimiento de los pilares estudiados.

PALABRAS ClaVE: Cemento Portland; Acero; Resistencia a la Compresión; Composite; Curado

ORCIDID:D.D. Tripura:(https://orcid.org/0000-0002-0191-1637);K.D. Singh:(https://orcid.org/0000-0001-5049-1408)

Copyright: (C) 2018 CSIC. This is an open-access article distributed under the terms of the Creative Commons Attribution 4.0 International (CC BY 4.0) License 


\section{INTRODUCTION}

Rammed earth construction techniques have gained much popularity across the world, due to its varied sustainable benefits such as availability of construction soil locally, low consumption of energy, easy construction procedure, eco-friendly etc., (1-10). Study on properties of soil, its suitability, and behaviour of structural rammed earth elements such as walls, columns etc., have been made $(1,2,4,5,10-18)$. Further, in the literature use of $5-10 \%$ cement for the construction of cement stabilised rammed earth (CSRE) has been reported $(3,4,14,19-21)$.

Attempts have also been made to study the pullout behaviour of deformed and plain rebars and bamboo in unstabilised and cement stabilized rammed earth (CSRE) $(22,23)$.

Structural behaviour (e.g. load and deformation capacities, load eccentricity effect) of unstabilised columns and unreinforced CSRE (i.e. UCSRE) walls have been studied $(12,14,24)$. Gupta (18) reported the effect of diagonal and horizontal stirrups on the load-capacity $\left(P_{u s}\right)$ of steel reinforced CSRE columns. Studies have shown that bamboo can be a potential substitute to steel in structural concrete elements such as beams and columns $(25-27)$ and can improve the ductility of rammed earth wall under horizontal load (28). However, it is observed that only few countries have developed standard guidelines, handbooks etc., for earth construction that include various aspects such as selection of soil, equipment and techniques, testing procedures $(29-32)$.

Although significant progress has been made in the understanding of rammed earth techniques, the application of rammed earth in the construction sector remains limited, mainly arising from the lack of systematic study in their structural performances of rammed earth members such as beams, columns etc. With increasing number of modern building designers, seek to use earth materials in a more challenging and innovative ways such as the one shown in Figure 1 (33) the development of reliable and robust design guidelines for rammed earth construction, has become relevant. In this context, in this paper, an attempt has been made to investigate systematically, the structural behaviour (especially, load capacity; axial and lateral deformation; failure modes) of steel reinforced CSRE columns, under axial compression. The results of steel reinforced CSRE columns are further compared with the results obtained from unreinforced and bamboo reinforced CSRE columns.

\section{MATERIAL PROPERTIES AND EQUIPMENT}

Properties of soil confirming to Indian Standard IS 2720 Part 4 (34), IS 2720 Part 5 (35) and IS 2720 Part 7 (36) is shown in Table 1 and Figure 2, adopted

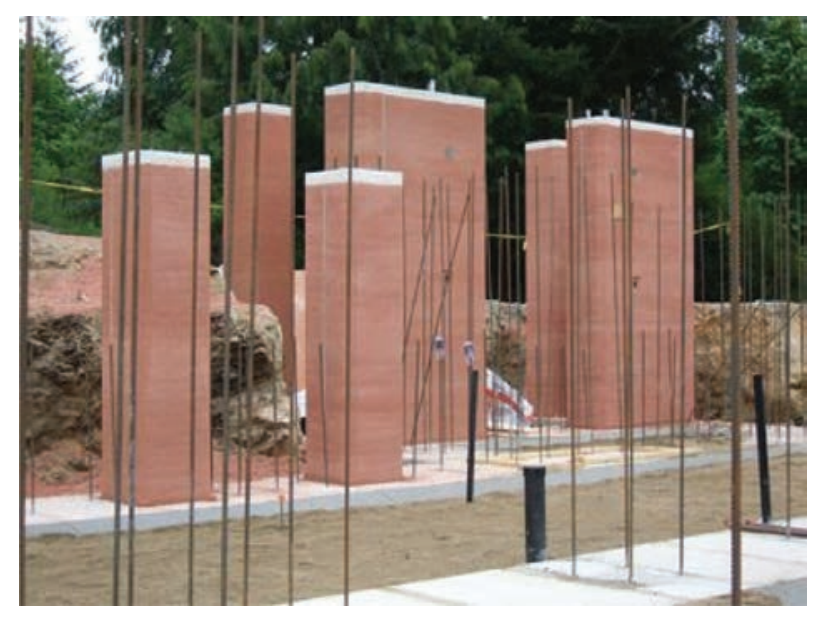

FIGURE 1. Steel reinforced rammed earth columns (Source: Clifton, 2015).

TABle 1. Properties of soil used

\begin{tabular}{lc}
\hline Soil property & Percentage value \\
\hline Grain size distribution: & \\
Sand & $79 \%$ \\
Silt & $13 \%$ \\
Clay & $8 \%$ \\
Atterberg limits: & \\
Liquid limit & $31.70 \%$ \\
Plastic limit & $22.90 \%$ \\
Plasticity index & $8.80 \%$ \\
Compaction characteristics: & \\
(a) Soil with 10\% cement & \\
Optimum moisture content & $19 \%$ \\
Maximum dry density $\left(\mathrm{kg} / \mathrm{m}^{3}\right)$ & 1710 \\
\hline
\end{tabular}

(Source: Tripura and Singh, 2015)

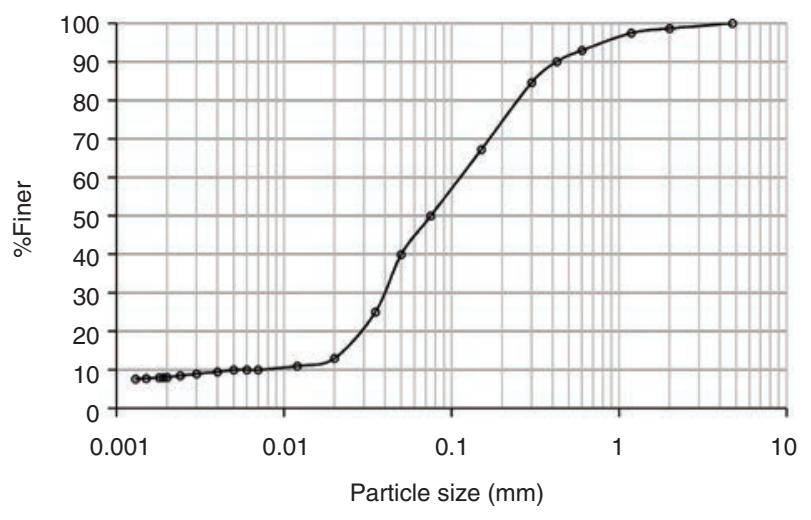

FIGURE 2. Grain size distribution. 
from earlier works by the authors $(8,10,23)$. Many researchers $(3,4,11,13,24,37)$ and standards $(30,38)$ also suggested varying soil types for rammed earth constructions. Likewise, mechanical properties such as compressive and bond strength of rammed earth specimens are adopted from the works by the authors and other researchers $(22,23)$. Furthermore, Tripura and Sharma (23) reported the tensile strength of bamboo (bambusa balcooa locally known as Uabang) to be $315 \mathrm{MPa}$. About $10 \%$ ordinary Portland cement (by mass of dry soil) conforming to IS 8112 (39) was used as stabilizer for production of test specimens throughout the experimental program. The initial and final setting time of cement are 40 and 180 minutes respectively having specific gravity of 3.09. Deformed steel bars $\left(\mathrm{F}_{\mathrm{e}}\right.$ 500 grade) of $6 \mathrm{~mm}$ and $8 \mathrm{~mm}$ diameters confirming to IS1786 (40) having $558 \mathrm{MPa}$ tensile strength was used as lateral and longitudinal reinforcement respectively.

A wooden mould (Figure 3a) of $150 \mathrm{~mm} \times 150$ $\mathrm{mm}$ in cross-section (inner dimension) of $20 \mathrm{~mm}$ thickness and $1.5 \mathrm{~m}$ height was used for making of columns. A $5 \mathrm{~kg}$ mild-steel rammer with $25 \mathrm{~mm}$ diameter solid handle, $1.02 \mathrm{~m}$ length and $70 \mathrm{~mm} \mathrm{x}$ $70 \mathrm{~mm}$ ramming face (Figure $3 \mathrm{~b}$ ) was used for compaction. Further, a $20 \mathrm{~mm}$ thick mild steel plate of size $148 \mathrm{~mm}$ x $148 \mathrm{~mm}$ with $12 \mathrm{~mm}$ diameter holes at four corners at about $30 \mathrm{~mm}$ away from the edge was employed (Figure $3 \mathrm{~b}$ ) to enable the insertion of (a)

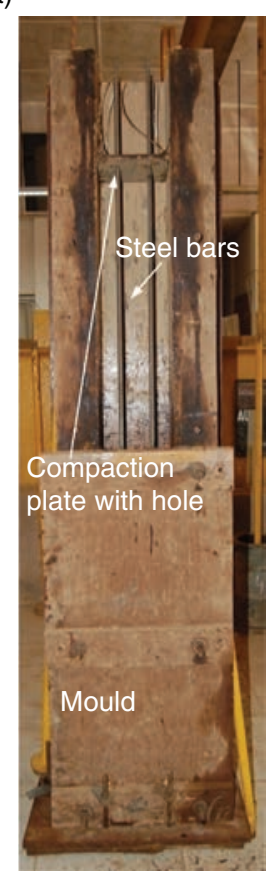

(b)

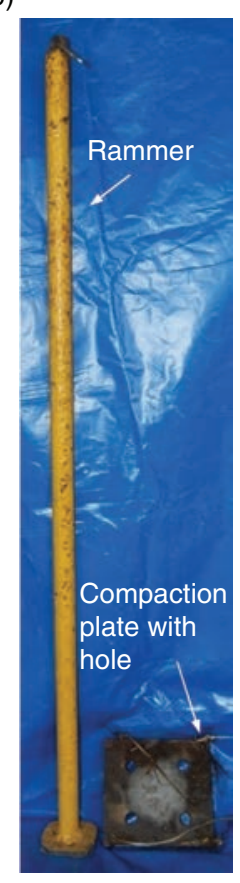

(c)

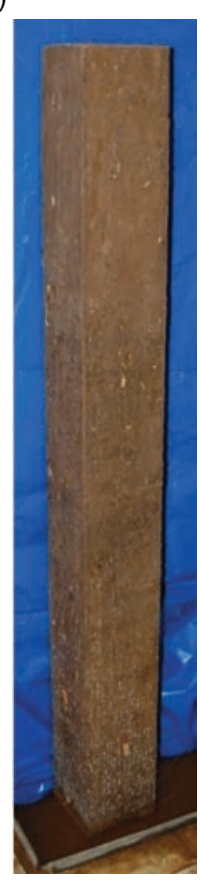

FIGURE 3. Details of equipment; (a) mould and reinforcement details; (b) rammer and compaction plate and (c) test specimen. vertical reinforcement. More details of reinforcement and compaction procedure have been described in the earlier work by the authors (27). Figure 3c shows a sample of a steel reinforced column.

\section{PRODUCTION AND TESTING OF SPECIMEN}

CSRE columns of size $150 \mathrm{~mm} \times 150 \mathrm{~mm} \times 1500$ $\mathrm{mm}$ (width $\mathrm{x}$ thickness $\mathrm{x}$ height) reinforced with steel (composite) were prepared for the experimental program. Lateral reinforcement at $200 \mathrm{~mm}, 100 \mathrm{~mm}$ and $50 \mathrm{~mm}$ centre-to-centre spacing (i.e., a tie spacing of about $133.3 \%, 67 \%$ and $33.3 \%$ respectively to the column width) were provided and denoted as SR200, SR 100 and SR 50, respectively comprising of at least three specimens for each series of columns. Two legged steel ties of $90 \mathrm{~mm} \times 90 \mathrm{~mm}$ size bent at $90^{\circ}$ and 4 longitudinal bars of $8 \mathrm{~mm}$ diameter were provided as lateral and longitudinal reinforcement as shown in Figure 4, which is similar to the earlier work by the authors (27). Table 2 outlines the reinforcement data where longitudinal reinforcement ratio $\left(\rho_{l}\right)$ of about $0.89 \%$ and lateral reinforcement ratio $\left(\rho_{\omega}\right)$ of about $0.63 \%, 1.26 \%$ and $2.51 \%$ were determined as follows [1,2].

$$
\begin{gathered}
\rho_{l}=\frac{A_{s l}}{A_{g}} \times 100 \\
\rho_{\omega}=\frac{4 \times A_{s t} \times c}{A \times s} \times 100
\end{gathered}
$$

where $\left(A_{s l}=\right.$ area of longitudinal reinforcement; $A_{s t}=$ cross sectional area of steel; $A_{g}=$ gross area

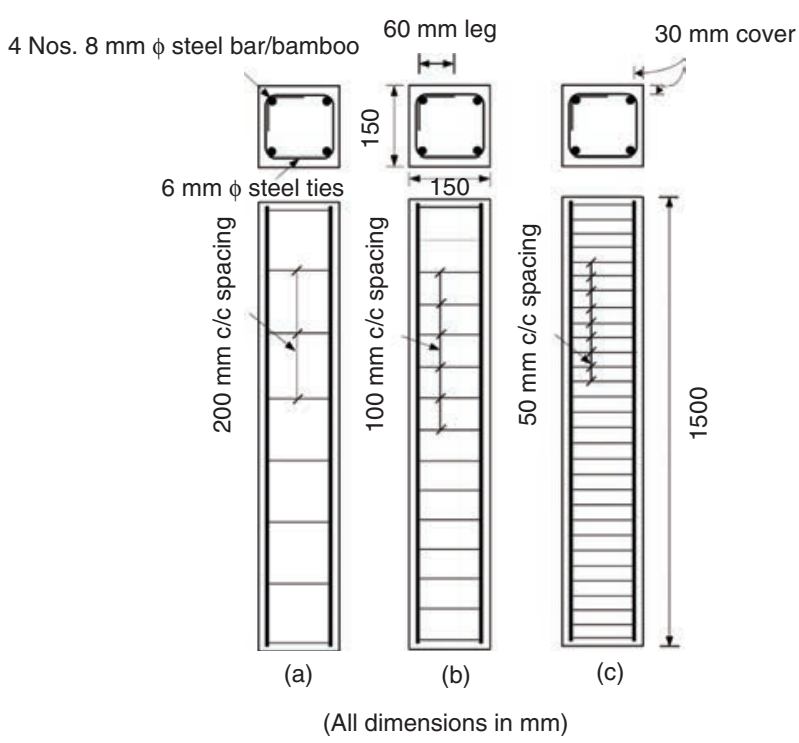

FIgURE 4. Details of column reinforcement: (a) $200 \mathrm{~mm}$ tie spacing; (b) $100 \mathrm{~mm}$ tie spacing and (c) $50 \mathrm{~mm}$ tie spacing. 
TABLE 2. Details of reinforcement data

\begin{tabular}{lcccccccc}
\hline Column & $\boldsymbol{b}(\mathbf{m m})$ & $\boldsymbol{d}(\mathbf{m m})$ & $\boldsymbol{h}(\mathbf{m m})$ & $\boldsymbol{s}(\mathbf{m m})$ & $\rho_{l}(\%)$ & $\rho_{w}(\%)$ & $\rho_{l}+\rho_{w}(\%)$ & Source \\
\hline BSR200 & 150 & 150 & 1500 & 200 & 0.89 & 0.63 & 1.52 & Tripura \& Singh, 2016 \\
BSR100 & 150 & 150 & 1500 & 100 & 0.89 & 1.26 & 2.15 & Tripura \& Singh, 2016 \\
BSR50 & 150 & 150 & 1500 & 50 & 0.89 & 2.51 & 3.41 & Tripura \& Singh, 2016 \\
SR200 & 150 & 150 & 1500 & 200 & 0.89 & 0.63 & 1.52 & Present study \\
SR100 & 150 & 150 & 1500 & 100 & 0.89 & 1.26 & 2.15 & Present study \\
SR50 & 150 & 150 & 1500 & 50 & 0.89 & 2.51 & 3.41 & Present study \\
\hline
\end{tabular}

of section; $A=$ cross sectional area of CSRE core bounded by centerline of outer tie; $s=$ spacing of tie; $c=$ side dimension of CSRE core)

Mass of dry soil-cement mix and compaction on each layer was controlled, through prior experimentation, to provide the equivalent of standard Proctor effort. Compaction energy was calculated using the formula given in ASTM D-698 (41) as follows [3]:

$$
E_{c}=\frac{n N W H}{V}
$$

Where $E_{c}=$ compaction energy $(\mathrm{kg} . \mathrm{cm} / \mathrm{cc}) ; n=$ number of compacted layer; $N=$ number of blows per layer; $W=$ weight of rammer $(\mathrm{kg}) ; H=$ height of fall of rammer; and $V=$ volume of mould.

The production of test specimens is as follows. First of all four steel bars were tied together at four corners of the tie/stirrups respectively at their bottom (Figure 3a) and then placed inside the mould followed by adding of wetted mix and placing of perforated steel plate over it (see Figures 3a and $3 \mathrm{~b}$ ). A rammer was dropped uniformly on the perforated plate from the height of $300 \mathrm{~mm}$ to compact the mix. Once, the layer was compacted fully the perforated plate was taken out and successive tie was placed over the compacted layer followed by pouring of wetted mix, replacing the perforated plate over it and compacting. This process continued until the desired height of column was achieved (Figure 3c). After de-moulding, the test specimens were cured (curing) for 28 days under wet gunny clothes followed by drying in ambient laboratory conditions for 4 weeks (as commonly practiced) prior to testing in order to avoid further loss of weight.

Detail of column test set up is shown in Figure 5. The lateral movement at the top of the column in the direction perpendicular to the plane was constrained by the loading system. Adequate care was taken to avoid overturning of columns at higher loads by providing steel bracket at top end of the column (Figure 5), in such a way that the axial movement of the column is not restricted.

A $500 \mathrm{kN}$ motorized hydraulic jack was used to apply vertical load on $250 \mathrm{kN}$ load cell which was

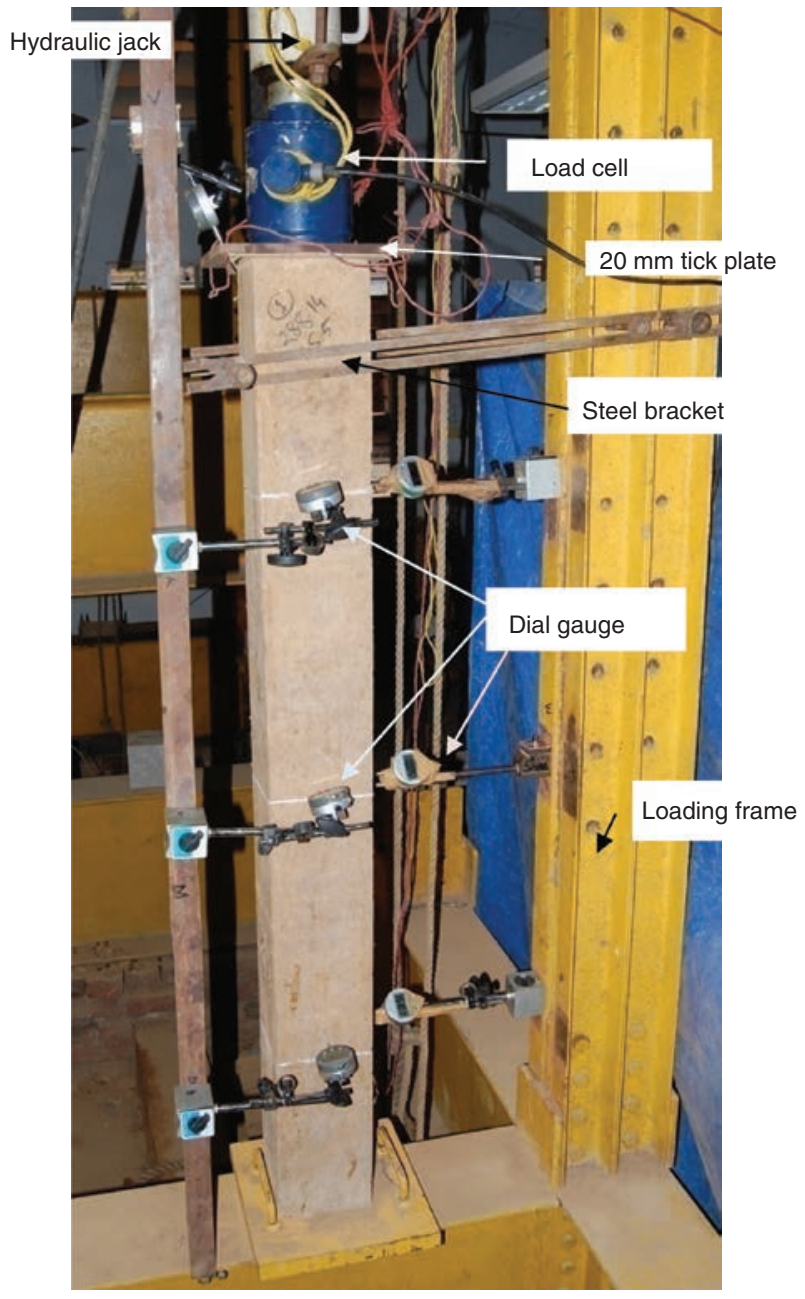

FIGURE 5. Details of column test setup.

placed in between the loading arm of the jack and the articulated plate resting on the test specimen. The loading rate was maintained at about $2.5 \mathrm{kN} /$ min (approximately) until failure (27). Six digital dial gauges were used to measure the lateral movement of column at every $10 \mathrm{kN}$ loading interval. A dial gauge was also fixed on top of each column to monitor the axial movement at every $5 \mathrm{kN}$ loading interval until failure. Due to precautionary measures 
some instruments were removed before the ultimate failure of the columns.

\section{RESULTS AND DISCUSSION}

\subsection{Steel reinforced columns with $200 \mathrm{~mm}$ tie spacing (SR200)}

Figure 6a shows the failure pattern of steel reinforced columns of $200 \mathrm{~mm}$ ties spacing (SR200). Columns did not show any sign of distress up to $60 \mathrm{kN}$ load, however at nearly $70 \mathrm{kN}$ load vertical cracks on CSRE close to longitudinal bars generated near the loading end, which eventually led to spalling of cover. This is attributed to outward buckling of steel bars in between the ties, thereby leading to localized failure at the loading end, with little or no failure impact on the rest of the column length. This implies that the lateral tie spacing provided is sufficiently large enough to allow lateral buckling of the longitudinal steel bars reinforcement, thereby leading to ultimate failure of the column. However, unlike bamboo reinforced columns, no rupture of the longitudinal steel bars was observed at the failure load. This may be attributed to higher tensile strength and ductility possessed by steel bars which is capable of resisting the lateral pressure offered by the inner core (CSRE) of the column. Similar pattern of failure was observed in BSR200 columns as shown in Figure 6b (27).

Failure of SR200 columns occurred close to the loading end. This can be attributed to development of localized stress concentration due to weak shear wedge zone resulting from platen effect as shown in Figure 7 in UCSRE column (27), leading to early failure of longitudinal steel reinforcement and

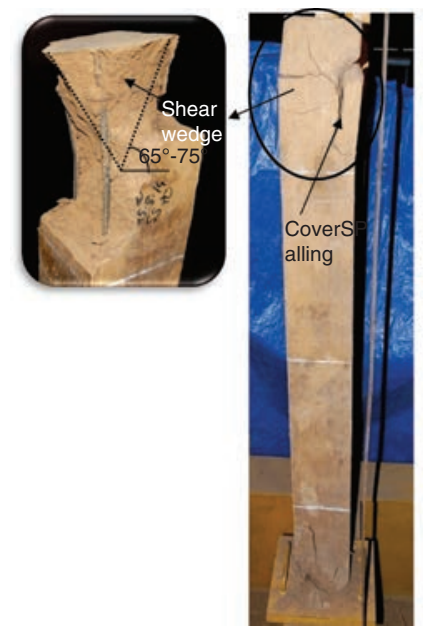

(a) SR200

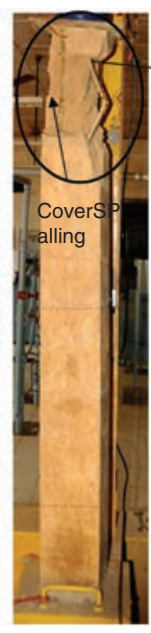

(b) BSR200

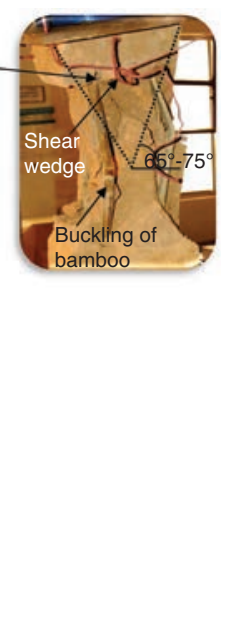

FIGURE 6. Failure pattern of column of $200 \mathrm{~mm}$ tie spacing.

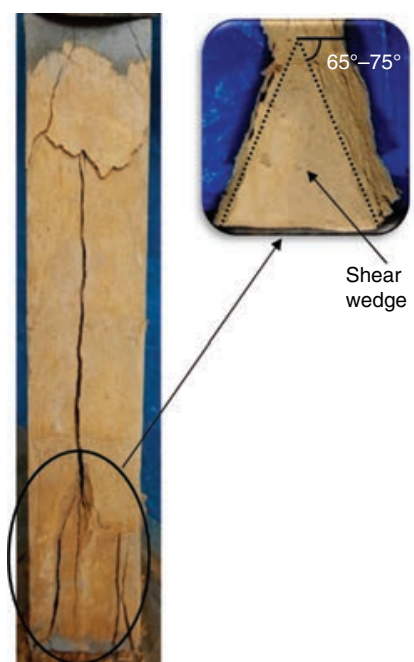

FIGURE 7. Failure pattern of UCSRE square column (Source: Tripura and Singh, 2015).

preventing further splitting of CSRE in presence of lateral ties. It can also be noticed from Figure 6a that the altitude of shear wedge pyramid is $\sim 97-167$ $\mathrm{mm}$, which is about $\sim 48 \%-83 \%$ of the tie spacing (i.e. lesser than the tie spacing of $200 \mathrm{~mm}$ ). Hence, it is possible that with relatively large tie spacing of $200 \mathrm{~mm}(\sim 133 \%$ of the column width) the confining effect from the ties is not sufficient to prevent such local failure due to formation of shear wedge. Lateral deformation $\left(\delta_{l}\right)$ of column is in the range of $0.5-2 \mathrm{~mm}$ from the axis at the corresponding load of $10-60 \mathrm{kN}$ (Figure 8). The location of column failure corresponds nearly to the location where the

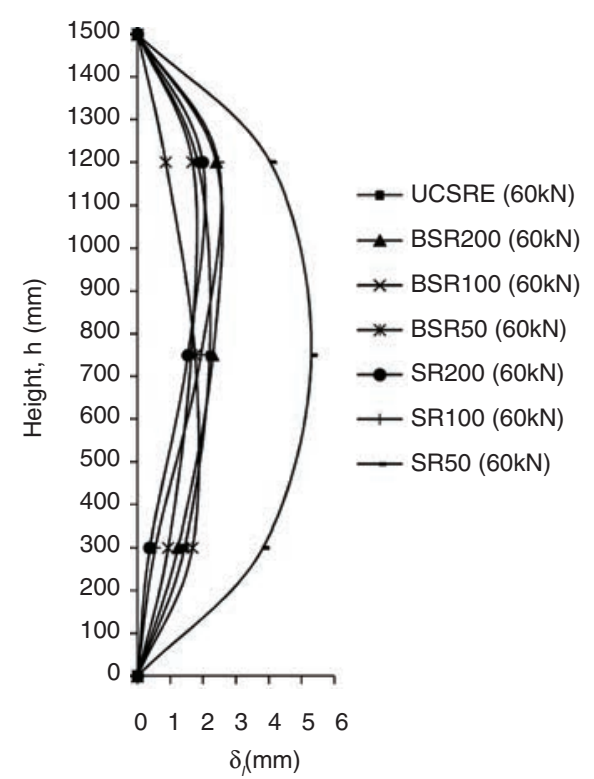

FIgURE 8. Load-lateral displacement $\left(P-\delta_{l}\right)$ curve. 
maximum $\delta_{l}$ occurred (Figs. 6 and 8). The average $P_{u s}$ of the column is determined to be $83.6 \mathrm{kN}$ with a standard deviation of $1.56 \mathrm{kN}$. No ties were found to yield/rupture. Table 3 shows the summary of column test results.

\subsection{Steel reinforced columns with $100 \mathrm{~mm}$ and 50 mm tie spacing (SR100 and SR50)}

Figure 9a shows the failure pattern of steel reinforced columns of $100 \mathrm{~mm}$ tie spacing (SR100). Unlike SR200 columns (see Section 4.1), the sign of distress is not seen in SR 100 columns even at $70 \mathrm{kN}$ load. However, as soon as the load was close to $80 \mathrm{kN}$ and above (i.e., at about $85 \%-90 \%$ of ultimate load), vertical cracks on CSRE close to longitudinal bars were generated near the support end, similar to the SR200 columns. Spalling of cover occurs near the mid-height of column where maximum lateral deformation happens, followed by bending of steel bars leading to ultimate failure. Similarly, no rupture of the longitudinal steel bars was observed at the failure load. Average $P_{u s}$ of column is about $92.9 \mathrm{kN}$ with a standard deviation of $2.37 \mathrm{kN}$, which is about $11.1 \%$ higher than SR200 columns. Lateral deformation $\left(\delta_{l}\right)$ of columns ranges from 0.6 to $2.6 \mathrm{~mm}$ at the corresponding load of 10 to $60 \mathrm{kN}$ (Figure 8). Relatively there is an enhancement of $\delta_{l}$ as compared to SR200 columns. Similar type of failure was observed in BSR 100 columns with slightly closer to the mid-height as shown in Figure 9b (27).

Figure 10a shows the failure pattern of steel reinforced columns of $50 \mathrm{~mm}$ tie spacing (SR50). Failure of this column is similar to SR 100 columns. $\delta_{l}$ of columns ranges from 0.7 to $5 \mathrm{~mm}$ at the corresponding load of 10 to $60 \mathrm{kN}$ (Figure 8). Failure occurs at the point where the maximum deformation occurred (Figures 8 and 9). Average $P_{u s}$ of column is about $109 \mathrm{kN}$ with a standard deviation of $1 \mathrm{kN}$, which is about $17.3 \%$ higher than the SR100 columns. Similar type of failure pattern (compression side crushing and tension side cracking) can be seen for both SR100 and SR50 columns, closer to the mid-height, along with spalling of cover near the support. Compression crushing for both SR 100 and SR50 extends to about $\sim 100 \mathrm{~mm}$ (i.e. around half the face width) at the face. However, presence of relatively distributed micro-cracks can be seen on the tension side of SR 50, in contrast to SR 100 where a well-defined macro-crack appears on the tension side of the failure zone. This led to the relatively smoother curvature of the failure zone in SR50 (see Figures 9a and 10a) and this can be attributed to the improved distributed stress with increased confinement effect, resulted from decreasing tie spacing (i.e. with higher $\rho_{w}$ ). The reason for the shifting of localized failure zone (or development of hinge)

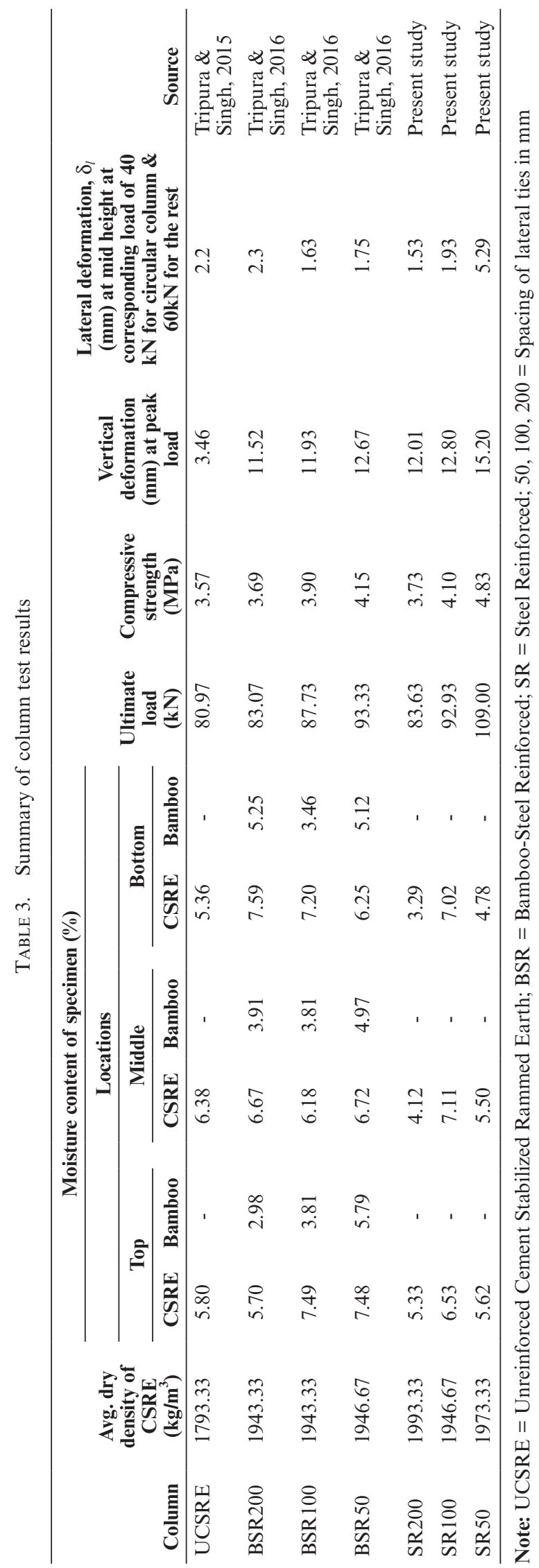




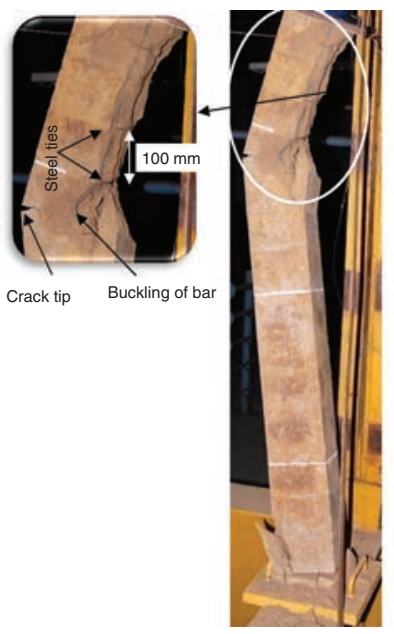

(a) SR100

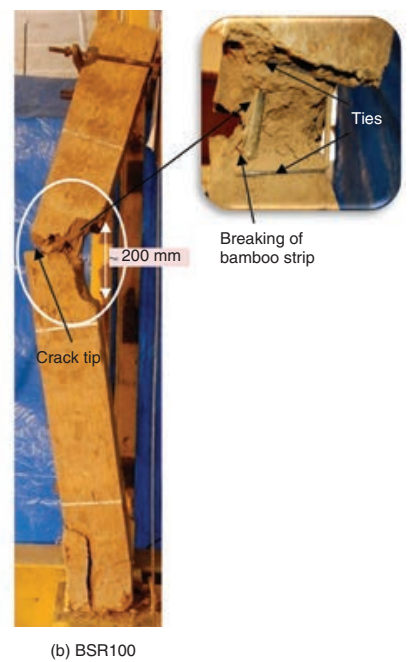

FIGURE 9. Failure pattern of column of $100 \mathrm{~mm}$ tie spacing.

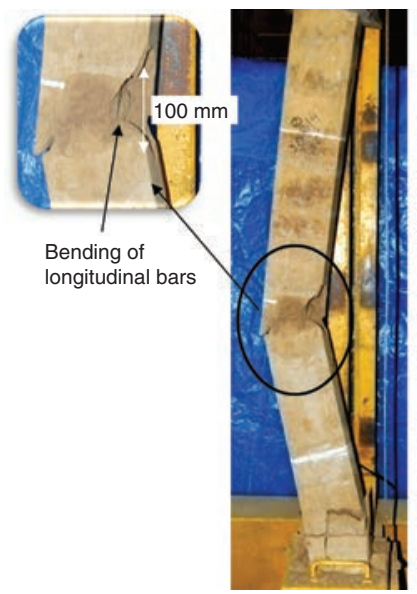

(a) SR50

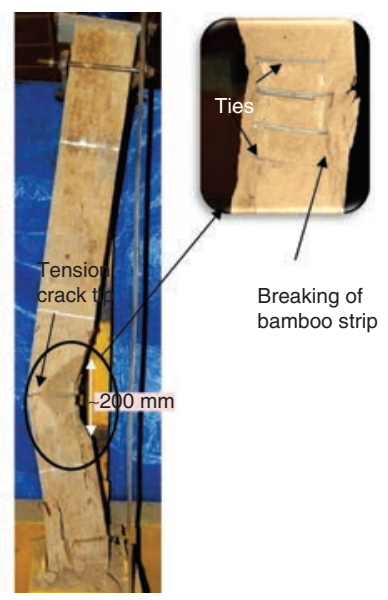

(b) BSR50
FIGURE 10. Failure pattern of column of $50 \mathrm{~mm}$ tie spacing.

closer to the mid-height for SR50 column in relation to that of SR100, can again be linked to better or improved distribution of the stresses as a result of increasing confinement effect from the ties. The relatively closer spaced ties in SR50 inhibited the possibility of premature formation of shear wedge failure zone near the supports (ties are known to provide/enhanced capacity), thereby greatly diminishing localized stress concentrations near the supports, which further arrests the possibility of localized cover spalling and buckling of longitudinal reinforcements closer to the supports. Again, no yielding of ties was observed during the entire process of experimentation. Similar type of failure pattern was observed in BSR50 columns as shown in Figure 10b with about $200 \mathrm{~mm}$ cover spalling and bending close to the mid-height (27).

\subsection{Load-axial deformation $\left(P-\delta_{v}\right)$ response of column}

Figure 11 shows the load-axial deformation $\left(P-\delta_{v}\right)$ curves of columns. Pre-peak and post-peak deformation was not recorded due to removal of dial-gauges attached to the column at about 60 $\mathrm{kN}$ load due to precautionary measures. It can be seen from the curves that with the increase in $\rho_{w}$ (or decrease in tie spacing), the $P_{u s}$ increases and the ductility property of the column is enhanced. It may be noted that when reinforcements are provided, measurement of post-peak deformations are made possible with the present test setup and unlike UCSRE columns as shown in Figure 7 (10,27), sudden failure (i.e. brittle) of columns did not occur. $\delta_{v}$ of column is about $71 \%$ higher than that of UCSRE columns at the corresponding load of $60 \mathrm{kN}$.

Unlike UCSRE and SR 200 columns, $P$ - $\delta_{v}$ curve behaves differently for SR100 and SR50 columns (Figure 11). It can be observed that the curves possess two peak points. During the ascending part of loading, confinement has little or no effect and the CSRE cover is visually free of cracks up to the first peak load equal to 65 to $75 \mathrm{kN}$ for SR 100 columns and 70 to $80 \mathrm{kN}$ for SR50 columns approximately, (i.e., at about $75 \%$ to $80 \%$ ultimate load). As the loading progressed there was a gradual fall of load by about 5 to $8 \mathrm{kN}$, which lasted for about 7 to 10 minutes, followed by increase in load up to second peak and beyond this there was gradual decrease in $P_{u s}$. Sudden fall in load after first peak can be attributed to gradual formation of microcracks on the tension side and de-bonding of the CSRE from the reinforcement leading to spalling of cover. Because of the tension cracks and spalling of cover, the effective cross-section available to resist the axial load drops, thereby dropping the $P_{u s}$. At this stage, lateral CSRE strains increase significantly. As a result, the inner confinement becomes very significant. The CSRE core gains strength, while cover gradually disappears (Figs. 9a and 10a)

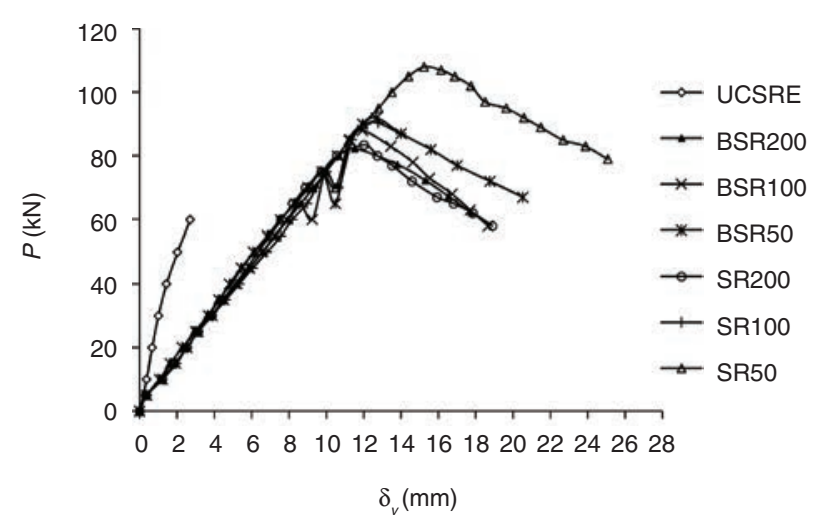

FIgURE 11. Load-axial displacement $\left(P-\delta_{l}\right)$ curve. 
at the failure zone. Generally, the load-deformation curve for the specimen shows a strength gain and reaches a second peak equal to average load of 92.9 $\mathrm{kN}$ (SR100) and $109 \mathrm{kN}$ (SR50) respectively, when the CSRE core reaches the maximum stress. At this load level, the longitudinal steel bars tend to bend, whereas lateral steel or ties shows no sign of distress or deformation. Since, column has been tested under pure axial load; hence the ultimate load exerted on column is insufficient to cause deformation in ties due to shear as observed at failure. Similar type of deformation pattern was observed for BSR100 and BSR50 columns (27)

It can be seen that, unlike the studies made by Cusson and Paultre (42) on high strength concrete columns confined by rectangular ties, the $P_{u s}$ of column at second peak did not fall below the value at first peak, in the present study. On the other hand, specimens with low confinement (specimens SR200) did not show the second peak (UCSRE and SR200 columns), which is attributed to brittle nature of failure.

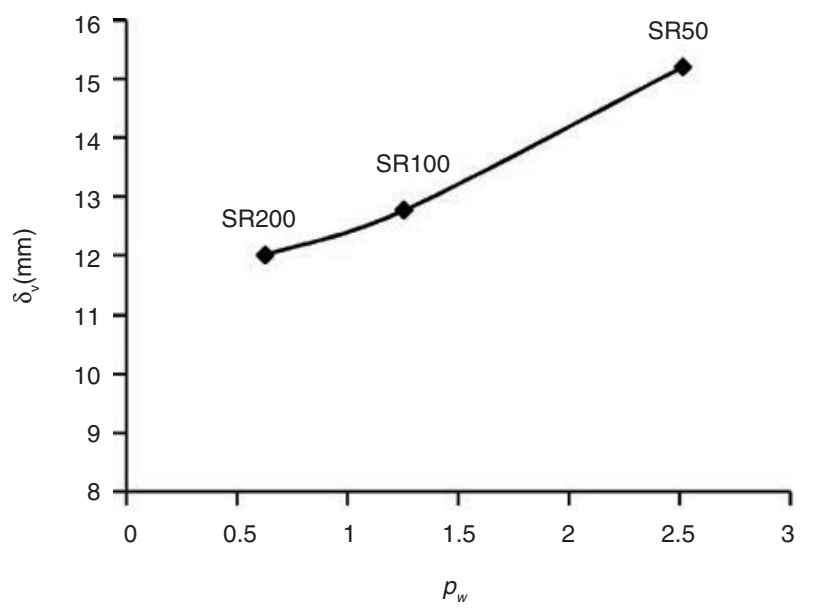

FIGURE 12. Effect of reinforcement on $P_{u s}$.

(a)

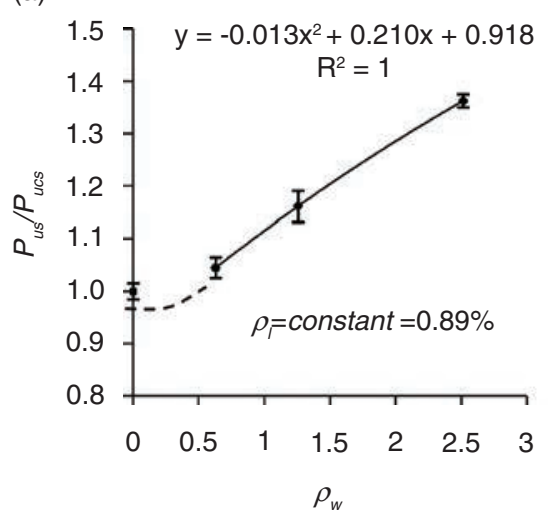

Figure 12 shows $P_{u s}-\delta_{v}$ curve with respect to variation in reinforcement ratio at the peak load. It is observed that SR50 column possess the maximum $P_{u s}$ as well as undergo maximum $\delta_{v}$ of about $19 \%$ to $25 \%$ higher than that of SR 100 and SR200 columns respectively. This may be attributed to enhancement of greater ductile property due to higher reinforcement ratio.

\subsection{Effect of reinforcement on $\boldsymbol{P}_{u s}$}

Figure 13a shows the effect of reinforcement on $P_{u s} . P_{u s}$ is normalized with respect to ultimate capacity of unreinforced column (i.e. $P_{u c s}$ ), as $P_{u r}\left(=P_{u s} / P_{u c s}\right)$. Positive effect of lateral steel confinement is clearly seen for $\rho_{w}>\sim 0.5$. There is an increase in $P_{u s}$ by about $30 \%$ when $\rho_{w}$ is increased by about $300 \%$. The plateauing effect of $P_{u s}$ at higher reinforcement ratio is consistent with the intuition that at vanishing tie spacing, the column would approach a rammed earth filled steel tube (just like concrete filled steel tubes with a finite strength value $(43,44,45)$. The increase in $P_{u s}$ with decreasing tie spacing (or increasing $\rho_{w}$ ) is consistent with similar studies done for steel reinforced concrete columns (42). At lower values of $\rho_{w}$ (i.e. $<\sim 0.5$ ), when the tie spacing is lesser than $200 \mathrm{~mm}$ (or 133\% of the column size), the effect of lateral confinement is not very significant on the column strength. Thus it can be seen that the overall response of the column $P_{u s}$ with confinement effect of the steel reinforcement can appears to follow a non-linear S-curve (i.e. a double curvature curve) plateauing at both the ends.

Figure 13b shows the effect of percent increase in reinforcement ratio to percent increase in axial $P_{u s}$. In this case, $P_{u s}$ is normalized with respect to average $P_{u s}$ of SR200 columns. $P_{u s}$ of columns is significantly affected by $\rho_{w}$ and it increases by about $11 \%$ to $30 \%$ when the percent $\rho_{w}$ was increased from $0.63 \%$ to $1.26 \%$ and $2.51 \%$, respectively. Again, similar type of effect was observed for BSR columns (27).

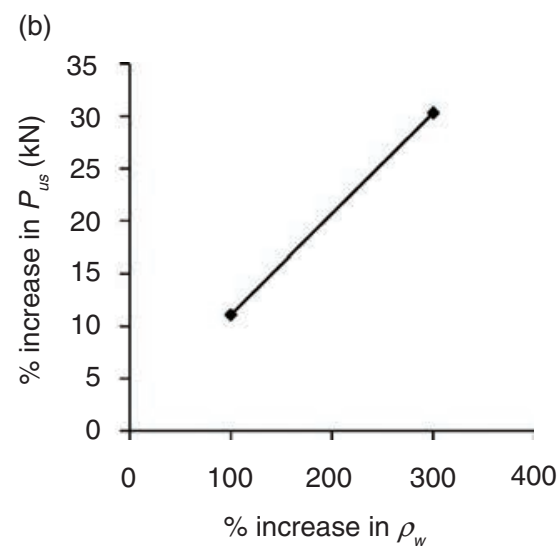

FIGURE 13. (a) Effect of $\rho_{w}$ on $P_{u s}$ of column and (b) effect of percent increase in reinforcement ratio on $P_{u s}$ of column. 


\section{SR AND BSR COLUMNS COMPARISON}

Figure 14 shows the $P_{u}$ relationship of BSR and SR columns with respect to $\rho_{w}$. It is observed that the $P_{u}$ increase gradually with the increase in reinforcement ratio in both BSR and SR columns. Furthermore, the SR columns possess higher $P_{u}$ by about $6 \%$ to $11 \%$ than BSR columns at the rate of two times increase in reinforcement ratio. Figure 15 shows the influence of longitudinal reinforcement type on $P_{u}$. Here the CSRE strength and tie spacing is considered as constant and material type for longitudinal reinforcement as variable. It can be seen that the difference in $P_{u}$ is negligible between BSR200 and SR200 columns. This shows that both bamboo and steel carries similar amount of load at this reinforcement ratio (i.e., $\rho_{w}=0.63$ ). However, the difference is highest between BSR50 and SR50 columns by about $17 \%$, which shows that the longitudinal steel becomes more effective and carries more

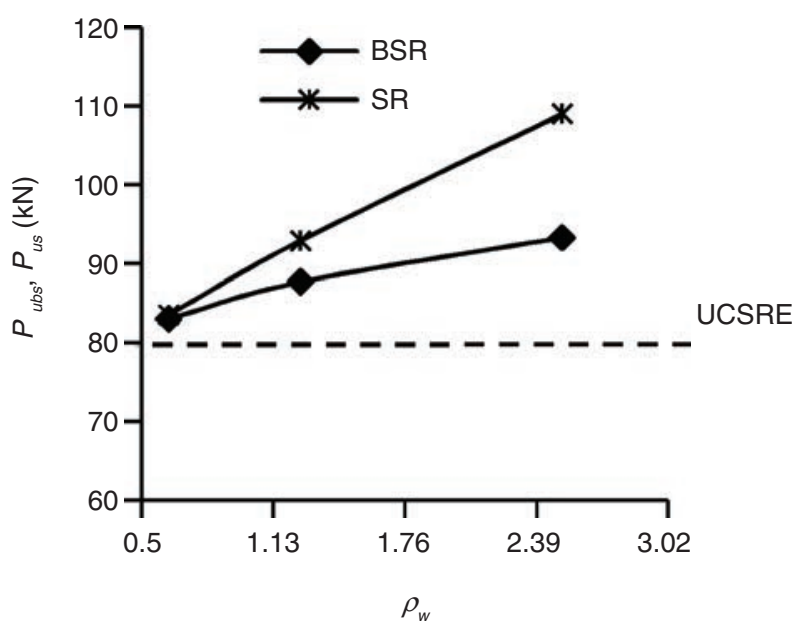

FIGURE 14. $\quad P_{u b s}$ and $P_{u s}$ of BSR and SR column with respect to $\rho_{w}$.

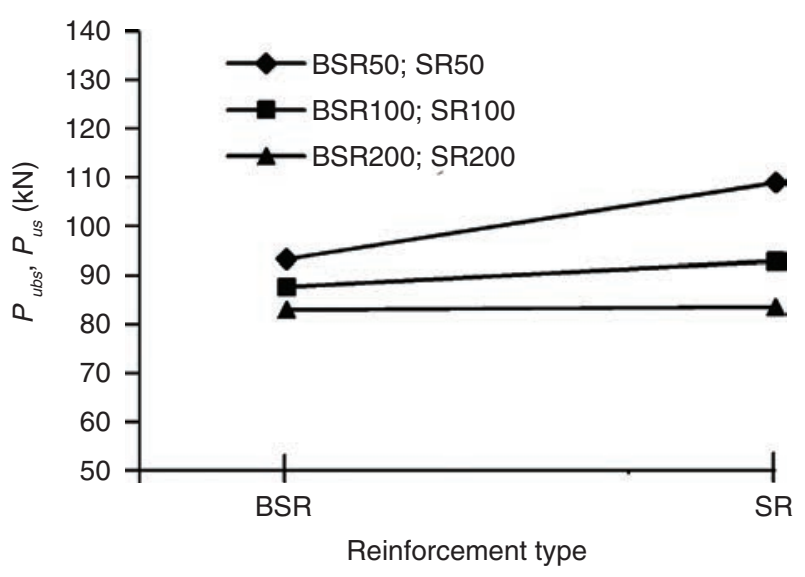

FIGURE 15. Effect of longitudinal reinforcement type on $P_{u}$. load than bamboo at $\rho_{w}$ equal to 2.51 . The reason for this difference can be due to steel being stronger material than bamboo.

The comparison of ultimate vertical deformation $\left(\delta_{u v}\right)$ and lateral deformation at $60 \mathrm{kN}$ load $\left(\delta_{l 60}\right)$ between SR and BSR CSRE columns are shown in Figs. 16a and 16b respectively. It can be seen that the values of $\delta_{u v}$ and $\delta_{l}^{60}$ for SR are found to be higher than that of BSR by $\sim 8 \%$ and $\sim 16 \%$ respectively, for greater tie spacing i.e., $100 \mathrm{~mm}$ and 200 $\mathrm{mm}$. However, a relatively sharp improvement in $\delta_{u v}$ and $\delta_{l 60}$ can be seen for SR when the tie spacing is reduced towards $50 \mathrm{~mm}$ from $100 \mathrm{~mm}$, in comparison to BSR wherein a gradual trend is maintained for all the tie spacing considered (i.e. $200 \mathrm{~mm}$ to 50 $\mathrm{mm}$ ). The enhanced deformation improvement trend in SR as compared to BSR, may be related to the improved confinement core strength achieved as a result of the higher strength in longitudinal steel (i.e. confinement effect has relatively increasing effect in mobilising the strength/stiffness of higher strength steel as compared to bamboo). Figure 17 shows the comparison of average compressive strength $\left(\sigma=P_{u} /\right.$ sectional area $)$ of all types of columns. It can be observed that SR50 column possess the highest strength and circular column the least with a value of 3.12 and $4.83 \mathrm{MPa}$ respectively. Table 3 shows the summary of column test results and comparison.
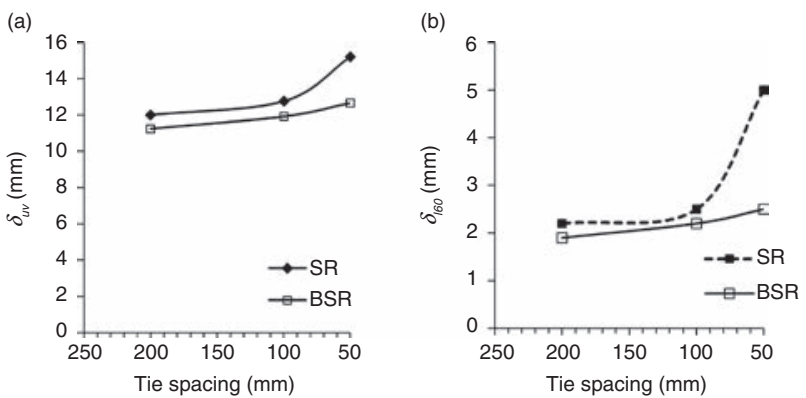

FIgURE 16. Comparison of SR and column on (a) axial deformation at ultimate load $\left(\delta_{u v}\right)$; and (b) lateral deformation at $60 \mathrm{kN}$ load $\left(\delta_{160}\right)$.

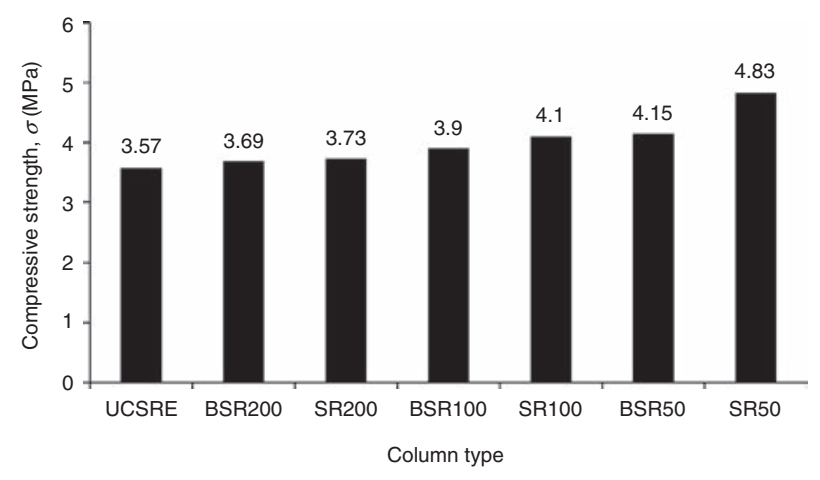

FIGURE 17. Compressive strength of different column types. 


\section{MOISTURE CONTENT AND DENSITY OF COLUMNS}

It is important to determine moisture content and density of the structural elements during the time of testing to achieve greater strength and durability of the rammed earth structures. Bui et al., (7) reported that, when the moisture content of rammed earth specimen is greater than $4 \%$, the compressive strength decreases quickly for all types of soil studied, and the effect is more in clayey soil than sandy soil. However, this effect is negligible to soil stabilized with $8 \%$ natural hydraulic lime and it was noted that the stabilization by hydraulic lime decrease the sensitivity to water of rammed earth material. Likewise, the effect of moisture content on strength and density of test specimens is expected to be negligible in the present study due to use of sandy soil and 10\% cement. Details of moisture content and density of CSRE columns during testing are presented in Table 3. In general, the average moisture content of the CSRE samples varies from $4.25 \%$ to $6.89 \%$ with a standard deviation of $0.13 \%$ to $0.91 \%$; and the average dry density varies from $1790 \mathrm{~kg} / \mathrm{m}^{3}$ to $1990 \mathrm{~kg} / \mathrm{m}^{3}$ with a standard deviation of $0.003 \%$ to $0.016 \%$ respectively. Analysis shows that there exists a marginal difference in average dry density and average moisture content between the specimens of the same series of column during testing. Tripura and Singh (8) reported that the difference in moisture content between the test specimens during testing ranging from of $1.79 \%-2.65 \%$ has negligible variation on strength and density between the test samples. Therefore, in the present study, the difference in moisture content between the test specimens during testing lies within this limit.

\section{SUMMARY AND CONCLUSIONS}

This paper presents a comparative study on the behaviour of CSRE column reinforced with steel and bamboo under axial compression. Based on the study following conclusions have been drawn:

1. $P_{u s}$ is found to increase with reduction in tie spacing. $P_{u s}$ of SR50 column is about $17 \%$ higher than BSR50 column and a negligible difference exists between the other column types.

2. The SR columns possess higher $P_{u}$ by about $6 \%$ to $11 \%$ than BSR columns at the rate of two times with increase in lateral reinforcement ratio.

3. The values of $\delta_{u v}$ and $\delta_{160}$ for SR are found to be higher than those of BSR by $\sim 8 \%$ and $\sim 16 \%$ respectively, for larger tie spacing i.e. $100 \mathrm{~mm}$ and $200 \mathrm{~mm}$.

4. Steel reinforced column may be used as structural member adjacent to walls for low-rise rammed earth houses due to its higher load carrying capacity. For better performance of columns biaxial loading test should be carried out. This type of column is not recommended for rigid frame skeleton structural system.

5. The reinforcement technique proposed in the current study can be adopted in the field for enhancement of strength and better performance of columns. However, durability test on corrosion of steel and alteration of bamboo to humidity and its bond properties need to be determined for better result.

\section{ACKNOWLEDGEMENTS}

The authors would like to thank Pratik, Bandana, Ranjit and Souvik for their constant support during the entire process of casting and testing of the test specimens.

\section{REFERENCES}

1. Easton, D. (1982) The rammed earth experience 1st Ed., Blue Mountain Press, Wilseyville, CA, (1982). https://www. amazon.com/Rammed-Earth-Experience-David-Easton/ $\mathrm{dp} / 9996936163$

2. Houben, H.; Guillaud, H. (1994) Earth constructionA comprehensive guide. Intermediate Technology Publications, London (1994). https://trove.nla.gov.au/work/ 10685474 ? q \&versionId $=46562438$

3. Walker, P. (1995) Strength, durability and shrinkage characteristics of cement stabilised soil blocks. Cem. Con. Comp. 17 [4], 301-310. https://doi.org/10.1016/0958-9465(95)00019-9

4. Jayasinghe, C.; Kamaladasa, N. (2007) Compressive strength characteristics of cement stabilized rammed earth walls. Construcc. Build. Mater. 21, 1971-1976. https://doi. org/10.1016/j.conbuildmat.2006.05.049

5. Ciancio, D.; Beckett, C.; Augarde, C.; Jaquin, P. (2016) First international conference on rammed earth construction: report. Proc. Institu. Civil Engrs. - Construcc. Mater. 169 [5], 271-275. https://www.icevirtuallibrary.com/doi/ abs/10.1680/jcoma.15.00038

6. Reddy, B.V.V.; Leuzinger, G.; Sreeram, V.S. (2014) Low embodied energy cement stabilised rammed earth building-A case study. En. Build. 68, 541-546. https://doi. org/10.1016/j.enbuild.2013.09.051

7. Bui, Q.B.; Morel, J.C.; Hans, S.; Walker, P. (2014). Effect of moisture content on the mechanical characteristics of rammed earth. Construcc. Build. Mater. 54, 163-169. https://doi.org/10.1016/j.conbuildmat.2013.12.067

8. Tripura, D.; Singh, K. D. (2014a) Characteristic properties of cement-stabilized rammed earth blocks. $J$. Mater. Civil Eng. 27 [7]. https://doi.org/10.1061/(ASCE) MT.1943-5533.0001170.

9. Tripura, D.; Singh, K.D. (2014b) Behaviour of cement stabilized rammed earth circular column under axial loading. Mater. Struct. 49 [1-2], 371-382. https://doi.org/10.1617/ s11527-014-0503-4

10. Tripura, D.; Singh, K. D. (2015) Axial load-capacity of rectangular cement stabilized rammed earth columns. Eng. Struct. 99, 402-412. https://doi.org/10.1016/j. engstruct.2015.05.014

11. Hall, M.; Djerbib, Y. (2004) Rammed earth sample production: Context, recommendations and consistency. Construcc. Build. Mater. 18 [4], 281-286. https://doi. $\mathrm{org} / 10.1016 / \mathrm{j}$. conbuildmat.2003.11.001

12. Maniatidis, V.; Walker, P. (2008) Structural capacity of rammed earth in compression. J. Mater. Civil Eng. 20 [3], 230-238. https://doi.org/10.1061/(ASCE)0899-1561(2008) $20: 3(230)$ 
13. Burroughs, S. (2008) Soil property criteria for rammed earth stabilisation. J. Mater. Civil Eng. 20 [3]. https://doi. org/10.1061/(ASCE)0899-1561(2008)20:3(264)

14. Reddy, B. V. V.; Kumar, P. P. (2011) Structural behaviour of story-high cement-stabilized rammed earth wall under compression. J. Mater. Civil Eng. 23 [3], 240-247. http:// dx.doi.org/10.1061/(ASCE)MT.1943-5533.0000155

15. Bui, Q.B.; Hans, S.; Morel, J.C.; Do, A.P. (2011) First exploratory study on dynamic characteristics of rammed earth buildings. Eng. Struct. 33 [12], 3690-3695. https://doi. org/10.1016/j.engstruct.2011.08.004

16. Lindsay, R. (2012) Structural steel elements within stabilized rammed earth walling. -In Modern earth building-materials, engineering, construction and applications, Woodhead Publishing Series in Energy: Number 33, 461480 (2012).

17. Ciancio, D.; Augarde, C. (2013) Capacity of unreinforced rammed earth walls subject to lateral wind force: elastic analysis versus ultimate strength analysis. Mater. Struct. 46 [9], 1569-1585. https://link.springer.com/article/10.1617/ s11527-012-9998-8

18. Gupta, R. (2014) Characterizing material properties of cement-stabilized rammed earth to construct sustainable insulated walls. J. Case Studies Construcc. Mater. 1, 60-68. https://doi.org/10.1016/j.cscm.2014.04.002

19. Ngowi, A.B. (1997) Improving the traditional earth construction: a case study of Botswana. Construcc. Build. Mater. 11 [1], 1-7. https://doi.org/10.1016/S0950-0618(97)00006-8

20. Guettala, A.; Abibsi, A.; Houari, H. (2006) Durability study of stabilized earth concrete under both laboratory and climatic conditions exposure. Construcc. Build. Mater. 20 [3], 119-127. https://doi.org/10.1016/j.conbuildmat.2005.02.001

21. Tripura, D.; Das, S. (2017) Shape and size effects on the compressive strength of cement stabilised rammed earth. ASCE/ Library. http://dx.doi.org/10.1061/9780784480502.028

22. Walker, P. J.; Dobson, S. (2001) Pullout test on deformed and plain rebars in cement-stabilized rammed earth. $J$. Mater. Civil Eng. 13 [4], 291-297. https://doi.org/10.1061/ (ASCE)0899-1561(2001)13:4(291)

23. Tripura, D. Sharma, R (2013) Bond behaviour of bamboo splints in cement-stabilized rammed earth blocks. Inter. J. Sustain. Eng. 7 [1], 24-33. https://doi.org/10.1080 19397038.2012.757671

24. Miccoli, L.; Müller, U.; Fontana, P. (2014) Mechanical behavior of earthen materials: A comparison between earth block masonry, rammed earth and cob. Construcc. Build. Mater. 61, 327-339. https://doi.org/10.1016/j.conbuildmat 2014.03.009

25. Ghavami, K. (2005) Bamboo as reinforcement in structural concrete elements. Cem. Conc. Comp. 27 [6], 637-649. https://doi.org/10.1016/j.cemconcomp. 2004.06.002

26. Agarwal, A.; Nanda, B.; Maity, D. (2014) Experimental investigation on chemically treated bamboo reinforced concrete beams and columns. Construcc. Build. Mater. 71, 610 617. https://doi.org/10.1016/j.conbuildmat.2014.09.011

27. Tripura, D.; Singh, K. D. (2016) Axial load-capacity of bamboo-steel reinforced cement stabilised rammed earth column. Struct. Eng. Inter. (accepted). https://www. researchgate.net/publication/305846198_Axial_loadcapacity_of_bamboo-steel_reinforced_cement_stabilised_ rammed earth column

28. Gao, Z.; Yang, X.; Tao, Z.; Chen, Z.; Jiao, C. (2009) Experimental study of rammed earth wall with bamboo cane under monotonic horizontal load. $J$. Kunming University Sci. Tech. 34 [2], 1-4. http://en.cnki. com.cn/Article en/CJFDTOTAL-KMLG200902015.htm

29. NZS 4297:1998. Engineering design of earth buildings. Wellington, New Zealand. http://www.eastue.org/project/ linea-adobe/norme/NZD4297-1998-Engineering_Design_ of_Earth_Buildings.pdf

30. $\mathrm{A} \overline{\mathrm{S}} \mathrm{H} \overline{\mathrm{B}}$ 195:2002. Australian earth building handbook."Standards Australia, Sydney, Australia. https:// www.standards.org.au/standards-catalogue/sa-snz/ building/bd-083/hb--195-2002

31. IS 2110:2002. Code of practice for in-situ construction of walls in buildings with soil-cement. New Delhi, India. https://services.bis.gov.in:8071/php/BIS/IndStndrdLocatr/ ISDetails.php?ID=ODY $1 \mathrm{Mg} \% 3 \mathrm{D} \% 3 \mathrm{D}$

32. ASTM E2392/E2392M-10. Standard guide for design of earthen wall building systems. West Conshohocken, PA. https://www.astm.org/Standards/E2392.htm

33. Clifton. http://rammedearth.info/cliftons-rammed-earthblog/ravine-rammed-earthhouse/ravine-house-post-2/. Accessed on 18 June 2015

34. IS 2720 (1995) Part 4: Specification for methods of test for soils-grain size analysis. New Delhi, India. https://archive. org/details/gov.in.is.2720.4.1985

35. IS 2720 (1995) Part 5: Determination of liquid and plastic limit. New Delhi, India. https://archive.org/details/gov. in.is. 2720.5 .1985

36. IS 2720 (2002) Part 7: Determination of water content-dry density relation using light compaction. New Delhi, India. https://archive.org/details/gov.in.is.2720.7.1980

37. Bahar, R.; Benazzoung, M.; Kenai, S. (2004) Performance of compacted cement stabilized soil. Cem. Con. Comp. 26, 811-20. https://doi.org/10.1016/j.cemconcomp.2004. 01.003

38. NZS 4298:1998. Materials and workmanship for earth buildings. Wellington, New Zealand. https://shop.standards.govt.nz/catalog/4298\%3A1998\%28NZS\%29/view

39. IS 8112:1989. Specification for 43 grade ordinary portland cement. New Delhi, India. https://archive.org/details/gov. in.is. 8112.1989

40. IS 1786:1985. Specification for high strength deformed steel bars and wires for concrete reinforcement. New Delhi, India. https://infostore.saiglobal.com/en-au/standards/ bis-is-1786-1985-r2004--1056371/

41. ASTM D698-12. Standard test methods for laboratory compaction characteristics of soil using standard effort. West Conshohocken, PA. https://www.astm.org/Standards/ D698

42. Cusson D.; Paultre, P. (1994) High-strength concrete columns confined by rectangular ties. J. Struct. Eng. 120 [3], 783-804. https://doi.org/10.1061/(ASCE)0733-9445(1994) 120:3(783)

43. Gardner, H.J.; Jacobson, E.R. (1967) Structural behaviour of concrete filled steel tube. J. Amer. Con. Inst. 64 [7], 404413.

44. Han, L.H. (2000) Test on concrete filled steel tubular columns with high slenderness ratios. Adv. Struct. Eng. Inter. J. $3[4], 337-344$. https://doi.org/10.1260/1369433001502265

45. Patton, M.L.; Singh, K.D. (2014) Finite element modelling of concrete-filled lean duplex stainless steel tubular stub columns. Inter. J. Steel Struct. 14 [3], 619-632. https://link. springer.com/article/10.1007/s13296-014-3020-y 